\title{
Synthesis and characterization of new methacrylate based hydrogels
}

\author{
Paula Ferreira1', Paulo Calvinho², António Silvério Cabrita², Etienne Schacht ${ }^{3}$, Maria Helena Gil ${ }^{* *}$ \\ ${ }^{1}$ Department of Chemical Engineering, University of Coimbra, Portugal, ${ }^{2}$ Institute of Anatomic Pathology - CHPEBD, \\ Faculty of Medicine, Coimbra, Portugal, ${ }^{3}$ University of Ghent, Department of Organic Chemistry, Polymer Materials \\ Research Group, Institute of Biomedical Technologies (IBITECH).
}

*Correspondence:

M. H. Gil

University of Coimbra

Department of Chemical Engineering,

Polo II, Pinhal de Marrocos,

3030-290 - Coimbra, Portugal

E-mail: hgil@eq.uc.pt

\begin{abstract}
Hydrogels have been used for several applications, including production of contact lenses, sanitary products and materials for wound dressing. The aim of this work was the development of new methacrylate based hydrogels. These materials present the advantage of being easily produced with different compositions and consequently different permeability and diffusion patterns. Therefore it becomes possible to synthesize hydrogels that can be used to immobilize a variety of compounds, such as drugs, proteins or even cells. During this work new polymers based on methacrylate monomers were prepared. Their characterization was accomplished by several techniques, e.g. Fourier Transform Infrared Spectroscopy (FTIR), swelling measurement, Differential Scanning Calorimetry (DSC) and evaluation of mechanical properties. Their subacute subcutaneous toxicity was also evaluated by using Wistar rats.
\end{abstract}

\section{INTRODUCTION}

Hydrogels can be defined as polymers that present the ability to swell in water or aqueous systems, without dissolving in them (Blanco et al., 1994). This swelling versus not dissolving capacity is achieved by cross-linking the polymer structure.

The development of hydrogels started in the beginning of the sixties, with the production of hydroxyethyl methacrylate (HEMA) based polymers (Wichterle et al., 1960), which presented a swelling capacity of 40-50\%. These hydrogels were applied mainly in the development of contact lenses that completely changed the course of Ophthalmology evolution. The need of optimisation of these lenses and to solve other problems in the medical field led to the development of a second family of hydrogels. The swelling capacity of these new polymers was between $70-80 \%$ and they made possible the application of this kind of material in many other fields. In the beginning of the eighties, the hydrogels suffered an intensive development. These new materials presented an even higher swelling $(>100 \%)$ than the ones that already existed. These highly hydrophilic polymers were mainly used in sanitary products like dippers (Garner et al., 1997), materials for wound closure (Chen et al., 1993; Weibin et al., 1993), production of intraocular and contact lenses (Seward, 1996; Wilson, 1998; Singer, 1996; Tighe, 1992), soil improvement and vegetal growth (Kazanskii et al., 1992).

Much of the existing work has been carried out on poly(acrylates) and its derivatives once the composition of such polymers can be easily changed in order to influence the permeability and diffusion patterns of the hydrogel. 
For this reason, it is possible to synthesize hydrogels that can be used to immobilize a great variety of compounds: drugs (Tae-Wan et al., 2003; He et al., 2004), proteins (Baptista et al., 2003; Patel et al., 2001) or even cells (Horák et al., 2004). In this way, different systems with different applications can be obtained.

The poly(acrylates) are also frequently used as implants. Their rubber-like flexibility when hydrated (which minimizes the mechanical damage of surrounding tissues), associated to their low surface tension (which minimizes cell adsorption and adhesion) are between their main advantages for such application (Corkhill et al., 1987).

Although hydrogels have a number of nonbiomedical applications (e.g. in agriculture), it seems that their use in the field of medicine and pharmacy is the most successful and promising (Rosiak et al., 2002). Part of this success can be a result of some important properties of hydrogels, like the ability to absorb aqueous solutions without loosing shape and mechanical strength. These characteristics are commonly found in many natural constituents of a human body, like muscles, tendons and cartilage. Moreover, hydrogels usually exhibit good biocompatibility in the contact with blood, body fluids and tissues. Much work has been done in the area of hydrogels, but the need of new materials that answer new challenges in several areas like medicine still exists. The present paper describes the synthesis of new polymers based on methacrylate monomers and their characterization by evaluation of some of their properties like swelling capacity, glass transition temperature and mechanical properties. The subacute subcutaneous toxicity of two homopolymers was also evaluated in Wistar rats.

\section{MATERIAL AND METHODS}

\section{Material}

Glyceryl monomethacrylate (GlMMA) was gently supplied by the Polymer Materials Research Group of the Ghent University, Belgium.

Isobutyl methacrylate (IBMA), 2-ethylhexyl methacrylate (EHMA), ethyleneglycol dimethacrylate (EGDMA) and triethyleneglycol dimethacrylate (TEGDMA) were purchased from Aldrich (Steinheim, Germany) and used as supplied.

Dimethylformamide from Aldrich (Steinheim, Germany), was dried using calcium chloride $\left(\mathrm{CaCl}_{2}\right)$. Benzoyl peroxide and potassium bromide $(\mathrm{KBr})$ were supplied by Sigma (Steinheim, Germany).

\section{Synthesis}

All the prepared polymers were based on GIMMA. Besides the correspondent homopolymers, copolymers were also synthesised by combining the GlMMA with either IBMA or EHMA in different proportions. The structures of these monomers are indicated in Figure 1.

In all cases one of the two crosslinkers, EGDMA or TEGDMA, was used to crosslink the polymers (Figure 2).

The monomers in different proportions were dissolved in $4 \mathrm{ml}$ of DMF to give a final concentration of

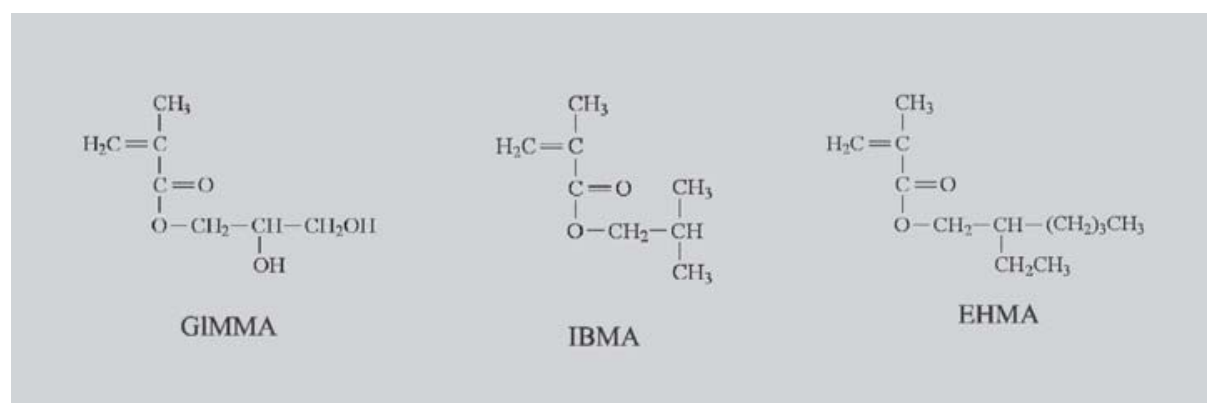

FIGURE 1 - Representation of the monomer structures.

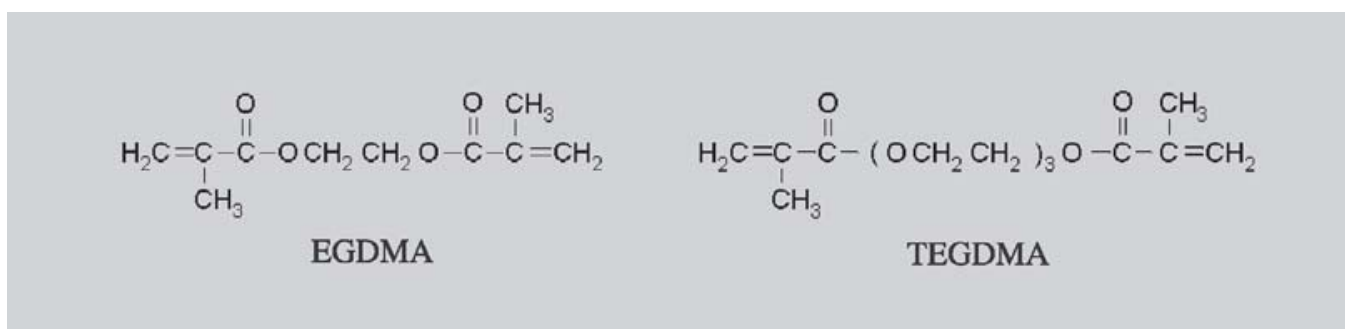

FIGURE 2 - Representation of the crosslinkers structures. 
$40 \%(\mathrm{w} / \mathrm{v})$. To this solution, were also added the crosslinking agent and the initiator benzoyl peroxide (in the proportion of $0.5 \% \mathrm{~mol}$ in relation to monomers molecules). In order to avoid oxygen inhibition, helium was bubbled in all the solutions for 5 minutes. Table I shows the six different polymers prepared with different proportions of the comonomers and crosslinker.

The solutions prepared were injected between polypropylene plates (Figure 3 ) and treated in an oven at $60{ }^{\circ} \mathrm{C}$ for $48 \mathrm{~h}$. Once the polymerization was completed the films obtained were removed from the plates and immersed in water stirring for 24 hours to remove the DMF and then dried over phosphorous pentoxide $\left(\mathrm{P}_{2} \mathrm{O}_{5}\right)$ also for 24 hours at room temperature.

\section{Fourier Transform Infrared Spectroscopy (FTIR)}

The infrared spectra of all the dried polymers and monomers were obtained by using $\mathrm{KBr}$ plates. The sample: $\mathrm{KBr}$ proportion was of 1:100 in weight. The spectra were recorded in a spectrometer 1600-FTIR from Perkin Elmer Instruments on an average of 128 scans at a $4 \mathrm{~cm}^{-1}$ resolution.

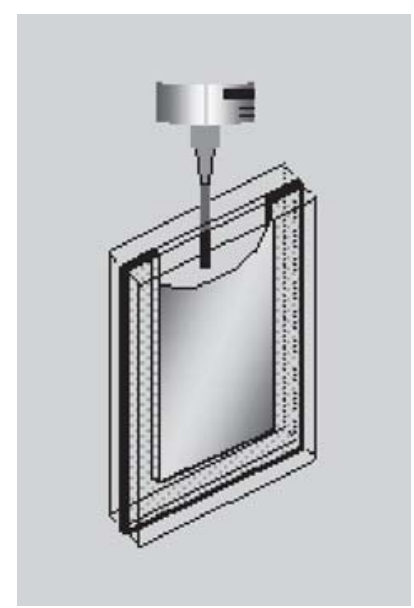

FIGURE 3 - Schematic representation of the plates used during polymerization.

\section{Water sorption capacity}

In order to determine the swelling, the polymers were primarily dried until constant weight at $60^{\circ} \mathrm{C}$ under vacuum conditions. The weight of the dried sample was obtained $\left(\mathrm{W}_{\mathrm{d}}\right)$. These samples were then immersed in water at room temperature and were weighted at different times until a maximum weight was achieved $\left(\mathrm{W}_{\mathrm{s}}\right)$. The swelling ratio was evaluated by using the following equation:

$$
\text { Swelling ratio }(\%)=\left(\frac{W_{s}-W_{d}}{W_{d}}\right) \times 100
$$

where $W_{s}$ and $W_{d}$ correspond to the weight of the swollen sample and dried sample, respectively.

\section{Differential Scanning Calorimetry (DSC)}

The DSC technique was used to obtain the glass transition temperature, which means the temperature value at which the polymer presents a rubber-like structure.

This technique was performed in a DSC-2929 (TA Instruments) and translated by the computer program Thermal Analysis (TA Instruments). The results of this analysis were obtained directly in the form of a graph that represented the heat flow $\left(' \mathrm{Q} /{ }^{\prime} \mathrm{t}\right)$ versus temperature $\left({ }^{\circ} \mathrm{C}\right)$. The samples $(10.00 \pm 0.04 \mathrm{mg})$ were sealed into DSC aluminum pans. An empty aluminum pan was used as reference material. The samples were studied at heating and cooling rates of $10{ }^{\circ} \mathrm{C} / \mathrm{min}$ between -150 and $200^{\circ} \mathrm{C}$. The negative values of temperature were obtained by using liquid nitrogen as the refrigerant.

All the polymers were characterized by this technique in the dried and in the hydrated state.

\section{Mechanical analysis of the polymers}

A method that has received attention since some years ago for the characterization of pharmaceutical and

TABLE I - Initial monomer composition of the solutions to be polymerized

\begin{tabular}{|c|c|}
\hline Polymer & Abbreviation \\
\hline 99\%GlMMA + 1\% EGDMA & 99Gl1EG \\
\hline 95\%GlMMA + 5\% EGDMA & 95G15EG \\
\hline $99 \%$ GIMMA + 1\% TEGDMA & 99G11TEG \\
\hline 95\%GIMMA + 5\% TEGDMA & 95G15TEG \\
\hline 79\%GIMMA + 20\% EHMA + 1\% TEGDMA & 79G120EH1TEG \\
\hline $79 \%$ GIMMA $+20 \%$ IBMA + $1 \%$ TEGDMA & 79G120B1TEG \\
\hline
\end{tabular}


polymeric systems is texture profile analysis (TPA) (Jones et al., 1997; Jones et al., 2002; Andrews et al., 2005). Several mechanical parameters can be determined through TPA and these include hardness, cohesiveness, springiness and adhesiveness. Such parameters have been used in the development of several pharmaceutical systems to provide information relating to, for example, the ease of removal product from the container, the spreadability of the product on the substrate (e.g., skin, mucosa) and also, the potential bioadhesive properties of the formulation (David et al., 2002).

The mechanical properties of the swollen polymers were determined using a texturometer TPA-500 (LLOYD Instruments) in texture profile analysis. The samples were prepared with a surface area of $7.0 \mathrm{~cm}^{2}$ and an analytical probe like the one represented in Figure 4 compressed the sample twice, which means that two values for the hardness of the material were obtained.

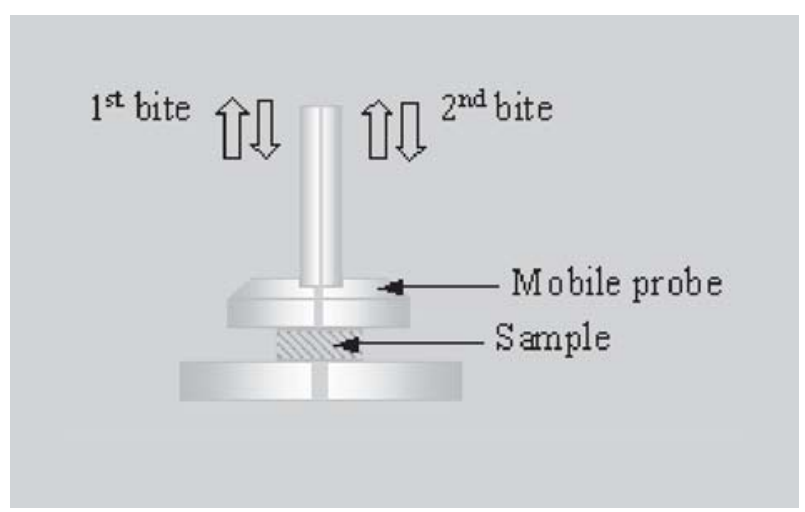

FIGURE 4 - Representation of the probe used to perform the texturometric tests.

All the tests were conducted until a $20 \%$ deformation of the sample was reached and a 1.5 seconds period of recovery was established between compressions. The experiments were conducted at room temperature and all analysis were performed using three replicate samples.

\section{Subacute subcutaneous toxicity}

To evaluate this parameter, 10 Wistar male rats 12 weeks old were used. All the animals were kept in quarantine for 10 days and then checked out for diseases. Once no sign of disease was found, the entire group was included in the study.

The animals were kept according to the actual legislation and were distributed in two groups in type IV cages. The rats were fed with synthetic food ration and received "ad libidum" acidulated water during the procedure.
Since the chemical and mechanical characteristics of the copolymers were very similar to the ones of the corresponding homopolymers, the toxicity studies were performed exclusively to the homopolymer that presented the highest swelling ratio, 99G11TEG.

\section{Polymer implantation}

The animals were anesthetised with ketamine chloridrate (Ketalar ${ }^{\circledR}$, Parke-Davis) $60 \mathrm{mg} / \mathrm{kg}$. In the middle upper left of the dorsum just at the left of the middle line, a tricotomy was performed, followed by a skin incision allowing access to the subcutaneous space where the polymer was inserted after washing it with pure ethanol and air dried. The skin was sutured with $3 / 0$ silk. In the opposite side the same procedure was taken without implantation of any polymer (positive control).

\section{Necropsy}

After the period of 10 days, the animals were euthanized with an excess of anaesthetic and then a complete necropsy was performed. All the animals were sacrificed individually and each one without the presence of the others.

The following organs were observed in situ and removed to histopathological study: heart, liver, right and left kidney, right and left lung, spleen, bladder, pancreas, intestinal tract and sternum. The skin where the material had been placed and the skin that had been manipulated without any implantation (positive control) were also removed. The negative control consisted in a sample of skin without any manipulation.

All the samples were fixed in formaldehyde, processed and included in paraffin blocks. These were then cut in $5 \mathrm{~mm}$ pieces and dyed with hematoxylin \& eosin for optical microscopy.

\section{RESULTS AND DISCUSSION}

\section{Fourier Transform Infrared Spectroscopy (FTIR)}

The results of the FTIR spectra for both monomers and polymers are presented in Table II.

By analysing the spectra of the polymers it was possible to verify that crosslinking reaction occurred, since a new band at $1112 \mathrm{~cm}^{-1}$ appeared on the polymers spectra. This transmittance band corresponds to the ether group stretching. Elimination of DMF from the polymers bulk was confirmed, since its characteristic band at $1690 \mathrm{~cm}^{-1}$ was not detectable in any case. 
TABLE II - FTIR results for both monomers and polymers.

\begin{tabular}{|c|c|}
\hline Sample & IR vmáx. $\left(\mathrm{cm}^{-1}\right)$ \\
\hline $\begin{array}{c}\mathrm{CH}_{3} \\
\mathrm{l}_{2} \mathrm{C}=\mathrm{C} \\
\mathrm{C} \\
\mathrm{C}=\mathrm{O} \\
\mathrm{O}-\mathrm{CH}_{2}-\mathrm{CH}_{-}-\mathrm{CH}_{2} \mathrm{OH} \\
\text { GIMMA } \mathrm{OH}\end{array}$ & $3600(\mathrm{vOH}) ; 2942\left(\mathrm{CH}_{3}\right) ; 1726(\mathrm{vCOO}) ; 1633(\mathrm{vC}=\mathrm{C}) ; 1177$ (vCOC ester). \\
\hline $\begin{array}{l}\mathrm{CH}_{3} \\
\mathrm{H}_{2} \mathrm{C}=\mathrm{C} \\
\mathrm{I} \\
\mathrm{C}=\mathrm{O} \\
\mathrm{O}-\mathrm{CH}_{2}-\mathrm{CH}_{-}-\left(\mathrm{CH}_{2}\right)_{3} \mathrm{CH}_{3} \\
\text { EHMA } \quad \mathrm{CH}_{2} \mathrm{CH}_{3}\end{array}$ & $2962\left(\mathrm{CH}_{3}\right) ; 1721(\mathrm{vCOO}) ; 1639(\mathrm{vC}=\mathrm{C}) ; 1169$ (vCOC ester). \\
\hline 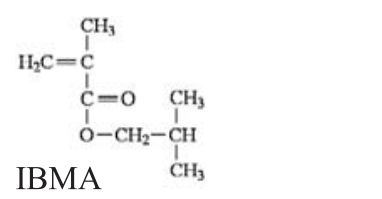 & $2962\left(\mathrm{CH}_{3}\right) ; 1721(\mathrm{vCOO}) ; 1639(\mathrm{vC}=\mathrm{C}) ; 1170$ (vCOC ester). \\
\hline $\begin{array}{l}\text { GlMMA + EHMA } \\
\text { Or GlMMA + IBMA } \\
\text { Crosslinker: EGDMA } \\
\text { TEGDMA }\end{array}$ & $3420(\mathrm{vOH}) ; 2940\left(\mathrm{CH}_{3}\right) ; 1734$ (vCOO); 1164 (vCOC ester); 1112 (vCOC ether). \\
\hline
\end{tabular}

\section{Water sorption capacity}

This parameter was evaluated for all synthesized polymers and the results were presented in Table III.

TABLE III - Swelling ratio of the polymers

\begin{tabular}{lc}
\hline Copolymers & Swelling Capacity (\%) \\
\hline 99G11EG & $105.05 \pm 2.05$ \\
95G15EG & $88.45 \pm 0.78$ \\
99G11TEG & $123.60 \pm 1.41$ \\
95G15TEG & $103.25 \pm 0.35$ \\
79G120EH1TEG & $72.45 \pm 1.06$ \\
79G120B1TEG & $74.75 \pm 1.63$ \\
\hline
\end{tabular}

The higher percentage of swelling corresponded to the homopolymer 99G11TEG. In fact, the GIMMA molecule possesses two hydroxyl groups in its structure and can be classified as a hydrophilic molecule when compared to the comonomers molecules (IBMA and EHMA) (Figure 1).

It was verified that the percentage of water sorption decreased with the increase of the percentage of crosslinker. This effect is due to two different factors: the lower hydrophilicity of the crosslinker molecule when compared with the one of the monomer (that diminishes the interaction of water and the copolymers) and the decrease on the mobility of the polymeric chains caused by the incorporation of the crosslinker in the polymer matrix. The chain mobility restriction will make the diffusion of water molecules into the polymer quite difficult and this effect will increase, as expected, with the increase in the crosslinker content. By comparing the effect of the crosslinkers, it was observed that for TEGDMA, it was obtained a higher \% of water sorption than with EGDMA. This effect is explained by the different length of the molecules. The TEGDMA is a larger molecule and for this reason when it binds different polymeric chains during polymerization, the distance between them will be higher. For this reason, the space available to accommodate water molecules inside the polymer matrix will be larger than when using EGDMA.

\section{Differential Scanning Calorimetry (DSC)}

This technique was used to evaluate the glass transition temperature of the polymers both in the dry and swollen state. By analysing the obtained curves that are 
represented in Figure 5 and Figure 6 (as an example for the polymer 79G120B1TEG), it is possible to determine the sample's glass transition temperature $\left(\mathrm{T}_{\mathrm{g}}\right)$. This value corresponds to the temperature at which the polymer starts to present a rubber-like structure.

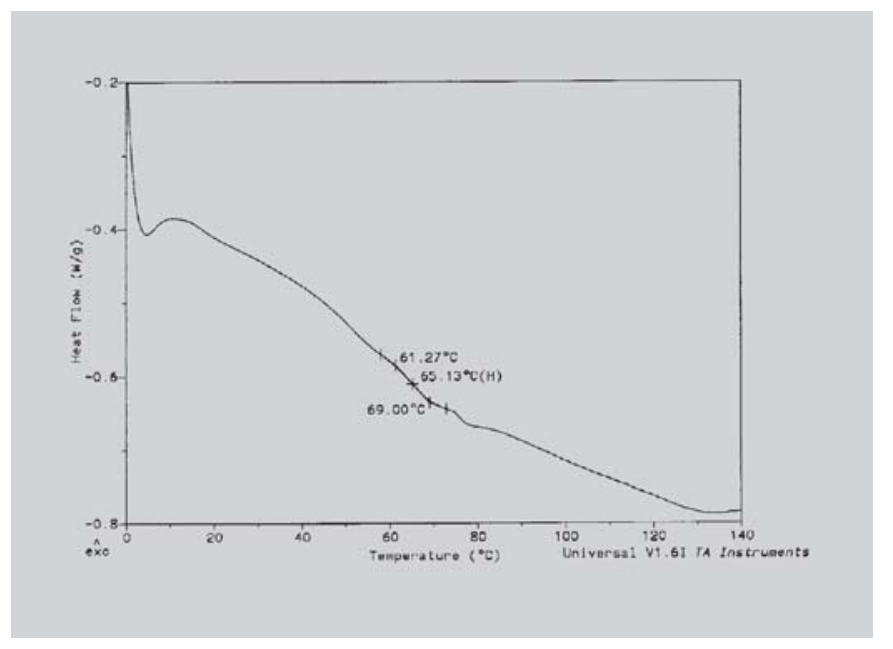

FIGURE 5 - Representation of the DSC curve obtained for the polymer 79G120B1TEG in the dry state.

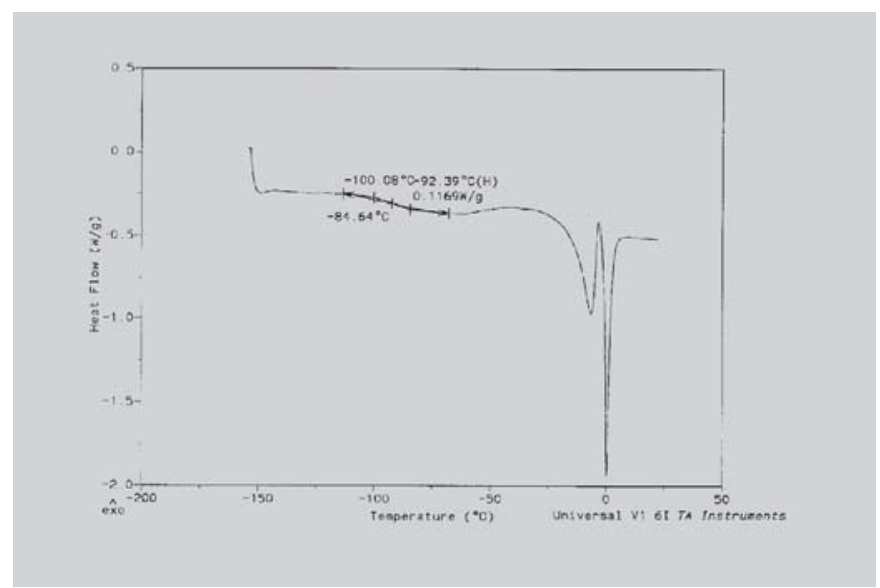

FIGURE 6 - Representation of the DSC curve obtained for the polymer 79G120B1TEG in the swollen state.

The values of $\mathrm{T}_{\mathrm{g}}$ obtained for all polymers are presented in Chart 1.

The $\mathrm{T}_{\mathrm{g}}$ values of the died polymers were about $66^{\circ} \mathrm{C}$, which means that the polymers are not very flexible at room temperature. In fact, the values of the $T_{g}$ do not suffer any significant variation either when one of the comonomers or crosslinkers is added or the crosslinker is changed. Usually, the presence of a crosslinking agent leads to a lower chain mobility (higher $\mathrm{T}_{\mathrm{g}}$ ). However, this effect can be contradicted since crosslinkers can induce formation of smaller chains, creating far more "endpoints"

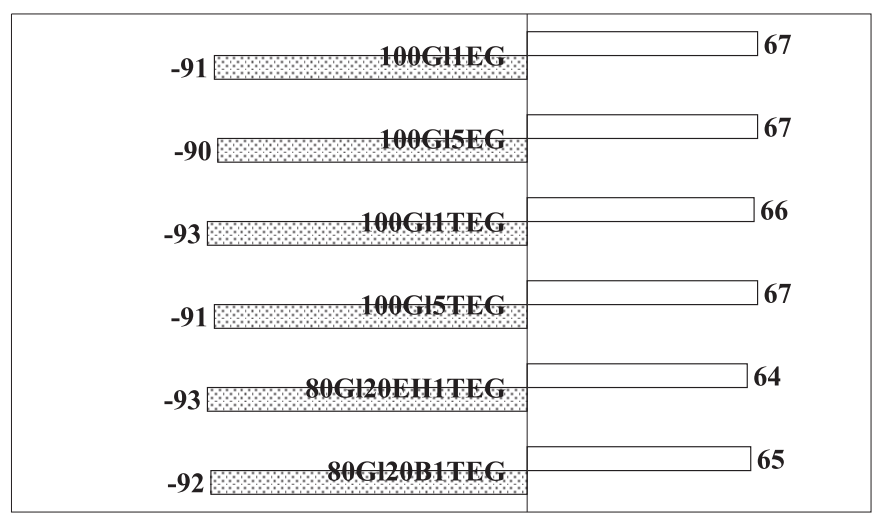

CHART 1 - $\mathrm{T}_{\mathrm{g}}$ of the dried polymers (white bars) and hydrated polymers (grey bars).

which have much higher mobility than the intern chain. This was probably the reason why the value of $\mathrm{T}_{\mathrm{g}}$ did not suffer the increment that could be expected by changing the percentage of crosslinker from 1 to $5 \%$. When the hydrated polymers were analysed, it was observed that the $\mathrm{T}_{\mathrm{g}}$ decreased to negative values, which means that they became flexible at room temperature. When the polymers absorb water into their matrix, the space between their chains will be fulfilled with water molecules. As a consequence, the distance between the polymeric chains will increase and so will their mobility. This effect in the chains higher freedom to move will be reflected in a decrease of the $\mathrm{T}_{\mathrm{g}}$ value. It was also possible to observe in the DSC curves of the swollen samples that the water fusion peaks were observed at around $0{ }^{\circ} \mathrm{C}$.

\section{Mechanical analysis of the polymers}

During the texture profile analysis tests that were performed to the hydrated polymers, the obtained results were directly translated by the software as a plot representing the force applied by the probe versus time. Considering that during these tests the probe is twice depressed into the sample under examination, two peaks of force were registered. Chart 2 shows, in general terms, the results usually obtained during the texture profile analysis tests.

From the resultant force/time plot several parameters can be determined (Table IV), such as:

- the hardness of the material (measured by the peak of force applied by the probe on the sample to obtain the $20 \%$ deformation). This value does not correspond necessary to the point of deepest compression, although it usually does for most materials);

- its cohesiveness (a measure of how well the sample withstands a second deformation relative to how it 
behaved under the first deformation. It is represented in Chart 2 by the ratio Area 2/Area 1);

- the springiness (is how well a product physically springs back after it has been deformed during the first compression. Springiness is measured by Distance 2/ Distance 1 in the Chart 2);

- and adhesiveness (measured by the force applied by the sample on the probe when it redraws after compression, represented in Chart 2 by the Area 3).

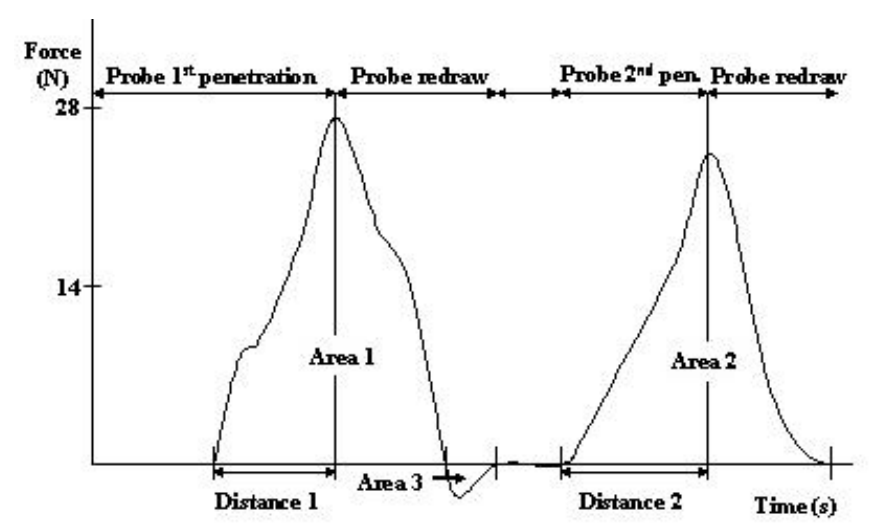

CHART 2 - General representation of texture profile analysis results.

Although two values for the hardness of the polymers were registered, the real measure of this parameter corresponds to hardness 1 that represents the peak force applied by the probe during the first compression.

Considering these values of hardness 1 , we could observe that they do not differ much between them. It was also possible to detect a small increase in the hardness of the polymers when the content of crosslinker was increased from 1 to $5 \%$. This higher rigidity of the materials is also justified by the lower chain mobility caused by the crosslinking agent, which, by establishing bonds between the different polymeric chains, inhibits their rearrangement when a force is applied. This difference is, however, discrete, which is coincident with the similar values of $\mathrm{T}_{\mathrm{g}}$ determined for all the samples. This capacity of realigning the polymeric chains also applies to the interpretation of the springiness values. The value of this parameter is closely related to the capacity of a material to recover from the first compression and presents higher values on the membranes that realign their chains more easily, i.e., more elastic membranes or less hard ones. For this reason, the polymers that contain one of the comonomers EHMA or IBMA, which are the ones with lowest hardness values, are also the ones with higher values of springiness.

Considering the values obtained for the cohesiveness of the materials it was concluded that they were all around one. Since cohesiveness can be defined as the tendency of a material to adhere to itself, these values indicate that the samples easily withstand a second deformation, or in other words, that their behaviour during the second compression was very similar to the one presented during the first one.

Finally, the values of adhesiveness were of zero to all the membranes and in fact, no sample presented an adhesive profile. This means that when the probe redraws from the samples these did not adhere to the base of the mobile probe and therefore no negative force was registered by the apparatus.

\section{Subacute subcutaneous toxicity}

The necropsy that was performed to all the organs did not reveal any significant anatomopathological changes. The only exception verified was the skin where the material had been placed (test group). Considering the positive control group, when observed by optical microscopy using the hematoxylin \& eosin coloration technique, no significant morphological alterations were observed, and therefore the surgical procedure does not interfere with the analysis of the results.

\section{Test group}

In the case of the skin where the polymer implantation took place, and by using the same

TABLE IV - Results of the texturometric analysis.

\begin{tabular}{lcccc}
\hline Polymer & Hardness 1 $(\mathrm{N})$ & Hardness 2 $(\mathrm{N})$ & Cohesiveness & Springiness \\
\hline 99G11EG & $24.93 \pm 0.25$ & $24.74 \pm 0.11$ & $1.0083 \pm 0.0021$ & $0.1860 \pm 0.0036$ \\
95G15EG & $25.90 \pm 0.26$ & $25.63 \pm 0.15$ & $0.9560 \pm 0.0342$ & $0.1963 \pm 0.0031$ \\
99G11TEG & $19.10 \pm 0.20$ & $19.08 \pm 0.19$ & $0.9990 \pm 0.0017$ & $0.2545 \pm 0.0014$ \\
95G15TEG & $23.47 \pm 0.15$ & $23.11 \pm 0.09$ & $0.9893 \pm 0.0015$ & $0.2105 \pm 0.0010$ \\
79G120EH1TEG & $18.63 \pm 0.25$ & $18.28 \pm 0.13$ & $0.9123 \pm 0.0025$ & $0.2642 \pm 0.0011$ \\
79G120B1TEG & $18.96 \pm 0.15$ & $18.96 \pm 0.14$ & $1.0027 \pm 0.0006$ & $0.2583 \pm 0.0009$ \\
\hline
\end{tabular}


coloration technique for optical observation, it was possible to identify fragments of the material subcutaneously. Along the border of the polymer, it was detectable a reaction of the connective tissue, traduced by a fibroblast proliferation, a slight increase of collagen fibers density and a discrete inflammatory mononuclear cell infiltrate (Figure 7).

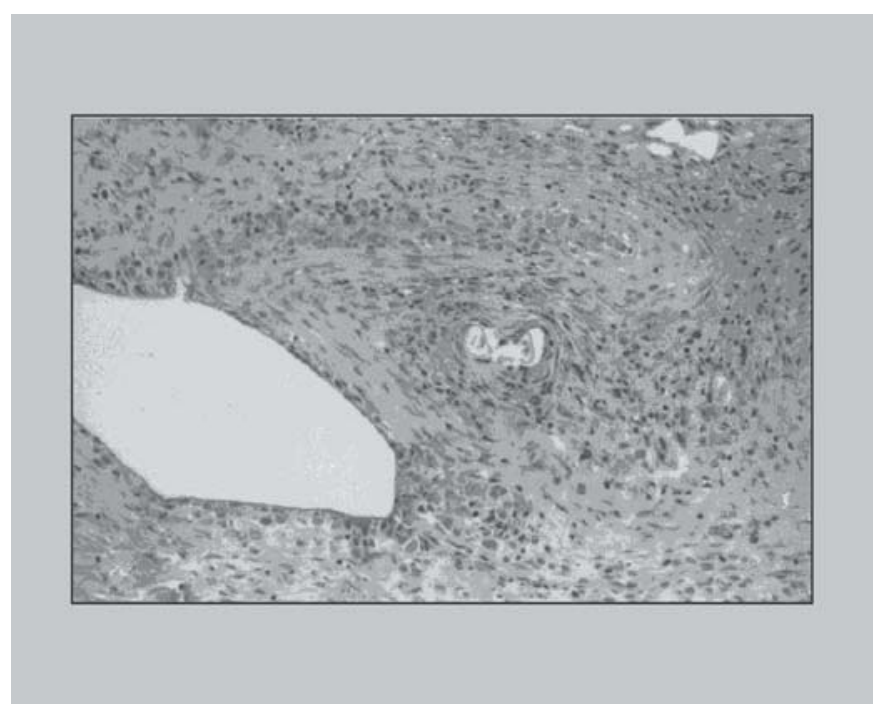

FIGURE 7 - Optical microscopy photography of the skin with the implanted polymer using the hematoxylin \& eosin coloration technique.

Considering the inexistence of histopathological pattern in any of the control groups, it was possible to determine that the connective tissue reaction was a consequence of the polymer implantation. This is a very mild reaction, with absence of polymorphonuclear cells (acute inflammatory response) and nuclear atypia, which is compatible with the natural enclosure of a foreign body by the tissue. In other words, the inflammation associated with implant placement led to the remodelling of the surrounding tissues, and finally, capsule formation, which means that the normal process of wound healing took place.

\section{CONCLUSIONS}

Hydrogels are being exploited for a variety of biomedical applications, namely in the area of tissue engineering, in the development of matrices for the encapsulation of living cells and for the controlled release of pharmaceutically active molecules.

During this work, six different membranes were synthesized and characterized by different techniques. It was verified that all the polymers present high capacity to absorb water since the lowest value registered for swelling was $73 \%$. All the copolymers proved to be flexible at room temperature when hydrated and presented good values of cohesiveness and springiness. This means that the samples exhibit good elastic behaviour and can withstand subsequent deformations without compromising their structure.

The polymers were implanted subcutaneously in order to evaluate their subacute subcutaneous toxicity, and we can suggest that the normal process of wound healing occurred. In conclusion, the surrounding tissues to the implant remodelled in order to enclose the polymer and by this way a capsule was formed which is consistent with a process of normal scaring.

\section{RESUMO}

\section{Síntese e caracterização de novos hidrogéis à base de metacrilato}

Hidrogéis têm sido utilizados para diversas aplicações, incluindo produção de lentes de contato, produtos sanitários e materiais para encerramento de ferimentos. $O \mathrm{ob}$ jetivo deste trabalho consistiu no desenvolvimento de novos hidrogéis a base de metacrilato. Estes materiais apresentam a vantagem de serem facilmente produzidos com diferentes composições e conseqüentemente com distintas permeabilidades e padrões de difusão. Por este motivo, torna-se possivel sintetizar hidrogéis que possam ser usados para imobilizar uma grande variedade de compostos, tais como fármacos, proteínas ou mesmo células e tecidos. Neste trabalho foram preparados diferentes polímeros baseados em monômeros de metacrilato. A sua caracterização foi realizada através de diferentes técnicas, como Espectroscopia no Infravermelho com Transformada de Fourier (FTIR), avaliação da capacidade de intumescimento, Calorimetria Diferencial de Varredura (DSC) e avaliação das propriedades mecânicas. A sua toxicidade subaguda subcutânea foi também determinada utilizando ratos Wistar.

UNITERMOS: Hidrogéis. Metacrilatos. Toxicidade subaguda subcutânea.

\section{REFERENCES}

ANDREWS, G.P.; GORMAN, S.P.; JONES, D.S. Rheological characterisation of primary and binary interactive bioadhesive gels composed of cellulose derivatives designed as ophthalmic viscosurgical devices. Biomaterials, v. 26, n. 5, p. 571-580, 2005. 
BAPTISTA, R.P.; SANTOS, A.M.; FEDOROV, A.; MARTINHO, J.M.G.; PICHOT, C.; ELAÏSSARI, A.; CABRAL, J.M.S.; TAIPA, M.A. Activity, conformation and dynamics of cutinase adsorbed on poly(methyl methacrylate) latex particles. J. Biotechnol., v. 102, p. 241-249, 2003.

BLANCO, M. D.; REGO, J. M.; HUGLIN, M.B. Drug release with simultaneous dimensional changes from a new copolymeric hydrogel. Polymer, v. 35, n. 16, p. 3487-3491, 1994.

CHEN, J.; YANG, Y.; QUIAN, P.; MA, Z.; WU, W.; SUNG, P.; WANG, X.; LI, J. Drug carrying hydrogel base wound dressing. Radiat. Phys. Chem., v. 42, n. 4-6, p. 915-918, 1993.

CORKHILL, P.H.; JOLLY, A.M.; NG, C.O.; TIGHE, B.J. Synthetic hydrogels: 1. Hydroxyalkyl acrylate and methacrylate copolymers- water binding studies. Polymer., v. 28, p. 1758-1766, 1987.

GARNER, C.M.; NETHING, M.; NGUYEN, P. The Synthesis of a Superabsorbent Polymer. J. Chem. Ed., v. 74, n. 1, p. 95-96, 1997.

HE, H.; CAO, X.; JAMES LEE, L. Design of a novel hydrogel-based intelligent system for controlled drug release. J. Controlled Release, v. 95, p. 391-402, 2004.

HORÁK, D.; KROUPOVÁ, J.; SLOUF, M.; DVORÁK, P. Poly(2-hydroxyethyl methacrylate)-based slabs as a mouse embryonic stem cell support. Biomaterials, v. 25, p. 5249-5260, 2004.

JONES, D.S.; LAWLOR, M.S.; WOOLFSON, A.D. Examination of the flow rheological and textural properties of polymer gels composed of poly(methylvinylether-comaleic anhydride) and poly(vinylpyrrolidone): rheological and mathematical interpretation of textural parameters. $J$. Pharm. Sci., v. 91, n. 9, p. 2090-101, 2002.

JONES, D.S.; WOOLFSON, A.D.; BROWN, A.F. Textural analysis and flow rheometry of bioadhesive, antimicrobial oral gels. Pharm. Res., v. 14, n. 4, p. 450-457, 1997.
KAZANSKII, K.S.; DUBROVSKII, S.A. Chemistry and physics of "agricultural" hydrogels. Adv. Polym. Sci., v. 104, p. 97-133, 1992.

PATEL, M.P.; PAVLOVIC, P.; HUGHES, F.J.; KING, G.N.; CRUCHLEY,A.; BRADEN, M. Release of recombinant human bone morphogenetic protein-2 from heterocyclic methacrylate polymer systems. Biomaterials, v. 22, p. 2081-2086, 2001.

ROSIAK, J.M.; JANIK, I.; KADLUBOWSKI, S.; KOZICKI, M.; KUJAWA, P.; STASICA, P.; ULANSKI, P. Radiation Formation of Hydrogels for Biomedical Applications. Centre of Excellence "Lasers \& Biomaterials in Medicine" report $(2002$.

SEWARD, H. Hydrogel IOL offers variety of handling advantages. Ocul. Surg. News, v. 7, n. 8, p. 13, 1996.

SINGER, H.W. Hydrogels work well, but different implant technique needed. Ocul. Surg. News, v. 7, n. 10, p. 8-9, 1996.

TAE-WAN, L.; JIN-CHUL, K.; SUNG-JOO, H. Hydrogel patches containing Triclosan for acne treatment. Eur. J. Pharm. Biopharm., v. 56 p. 407-412, 2003.

TIGHE, B. Eye contact. Chemistry in Britain, March, 1992.

WEIBIN, W.; PEIZHI, S.; XINGGUO, W.; JINGHUI, L. Slow release of wound healing drug from hydrogel wound dressing prepared by radiation crosslinking method. Radiat. Phys. Chem., v. 42, n. 4-6, p. 947-948, 1993.

WICHTERLE, O.; LIM, D. Hydrophilic gels for biological use. Nature, v. 185, p. 117-118, 1960.

WILSON, E.D. U.S. foldable IOL market ready for first onepiece lens. EyeWorld, v. 3, n. 1, p. 33-153, 1998.

Recebido para publicação em 16 de junho de 2005. Aceito para publicação em 24 de maio de 2006. 